\title{
ЗМІНИ ВИДОВОГО СКЛАДУ МІКРОФЛОРИ ПІСЛЯ ВАКУУМНОЇ ТЕРАПІЇ ГОСТРИХ РАНОВИХ ДЕФЕКТІВ У ХВОРИХ ІЗ СИНДРОМОМ СТОПИ ДІАБЕТИКА
}

\begin{abstract}
Резюме. Згідно з даними експертів Всесвітньої організації охорони здоров'я, кількість хворих на цукровий діабет (ЦД) у світі на даний час перевищує 120 млн і продовжує зростати в геометричній прогресії. Прогнозується, що до 2030 р. на планеті буде до 360 млн хворих.

Мета дослідження - вивчити зміни кількісного та якісного складу мікрофлори при застосуванні вакуумної терапії гострих ран у хворих із синдромом стопи діабетика.

Матеріали і методи. На основі обстеження та лікування 76 хворих на цукровий діабет, ускладнений синдромом стопи діабетика, вивчено вплив застосування вакуум-терапії на видовий склад мікрофрлори гострих ран. Серед обстежених чоловіків було 49 (64,5 \%), жінок - 27 (35,5 \%) віком від 48 до 72 років. Середній вік пацієнтів склав $(64,7 \pm 4,5)$ року. Хворих на ЦД легкого ступеня було 12, середньої тяжкості - 47, тяжкого - 17. Усім проводили загальне клініко-лабораторне та інструментальне обстеження: об'єктивне обстеження, збір скарг та анамнезу захворювання, цитологічні, мікробіологічні та морфологічні дослідження, терапевтичний вплив вакууму забезпечували вакуум-апаратом АГАТ-ДНЕПР, з від'ємним тиском у діапазоні 80125 мм рт. ст. Кількісний та якісний склад мікрофлори гострої рани визначали за допомогою бактеріологічного дослідження ранового ексудату на день госпіталізації, 3; 6; 9 та 14 доби лікування.

Результати досліджень та їх обговорення. Вивчення наявності мікробних асоціацій у гострих ранах показало, що у 55,8 \% пацієнтів спостерігалося поєднання 2-3 видів мікроорганізмів, у 34,8 \% - 4-5 та у 9,4 \% була моноінсекція. Починаючи 36 доби, загальна щільність мікроорганізмів у групі хворих, які отримували вакуумну терапію, склала $(4,19 \pm 0,45) \lg$ КУО/г, що нижче, ніж у контрольній групі - $(5,88 \pm 0,66) \lg \mathrm{KУO/г}(\mathrm{p}<0,05)$. Доведено, що застосування вакууму для лікування гострих ран зменшує кількісний та видовий склад мікроорганізмів у ранових десректах, що, у свою чергу, дозволяє скоротити стаціонарне лікування хворих у середньому на $(4,1 \pm 1,6)$ ліжко-дня.
\end{abstract}

Ключові слова: цукровий діабет; синдром стопи діабетика; вакуумна терапія.

ВСТУп Згідно з даними експертів Всесвітньої організації охорони здоров'я, кількість хворих на цукровий діабет (ЦД) у світі на даний час перевищує 120 млн і продовжує зростати в геометричній прогресії. Прогнозується, що до 2030 р. на планеті буде до 360 млн хворих [1-3, 5, 8]. Синдром стопи діабетика (ССД), як пізнє ускладнення, протягом життя виникає у 70-80\% хворих на ЦД, призводячи до розвитку гнійно-некротичних уражень нижніх кінцівок у 50-79 \% хворих, які можуть бути безпосередньою причиною високих ампутацій. Ускладнені фрорми ССД супроводжуються утворенням відкритих ранових десектів і післяопераційних ран, які характеризуються високою контамінацією та широким спектром мікроорганізмів, що значною мірою впливає на перебіг фраз ранового процесу та подальшу тактику лікування [1, 4, 5-7]. Динаміка перебігу ранового процесу та загоєння ран значною мірою залежать від характеру мікрофрлори у вогнищі гнійно-запального ураження. На сьогодні однією із актуальних методик місцевого лікування ран $€$ вакуумтерапія із значним позитивним впливом на рановий процес, але її вплив на зміну кількісного та видового складу мікросрлори гострих ранових десректів у хворих із синдромом стопи діабетика вивчено не достатньо, а тому вимагає подальших досліджень.

Метою дослідження було вивчити вплив вакуумної терапії на мікрофрлору гострих ран у хворих на цукровий діабет, ускладнений синдромом стопи діабетика.

МАТЕРІАЛИ I МЕТОДИ Робота ґрунтується на матеріалах комплексного обстеження та лікування 76 хворих із ускладненими фрормами ССД, які впродовж 2013-2016 рр. перебували на стаціонарному лікуванні в клініці загальної хірургії ДВНЗ “Тернопільський державний медичний університет імені І. Я. Горбачевського МОЗ України" (хірургічне відділення Тернопільської міської комунальної лікарні швидкої допомоги). У всіх пацієнтів було отримано інформовану згоду на запропоновані дослідження та методи лікування. Серед обстежених хворих чоловіків було 49 (64,5 \%), жінок - 27 (35,5 \%) віком від 48 до 72 років. Середній вік пацієнтів склав $(64,7 \pm 4,5)$ року. Хворих на ЦД легкого ступеня було 12, середньої тяжкості - 47, тяжкого - 17. Тривалість захворювання коливалась у межах від 8 до 37 років і в середньому складала $(12,8 \pm 4,2)$ року. Стадію компенсації ЦД при госпіталізації діагностовано у 26 хворих (34,22 \%), субкомпенсації - у 39 (51,31 $\%)$, декомпенсації - у $11(14,47 \%)$ пацієнтів. Хворих із невропатично-інорікованою фрормою (НІФ) ССД було 31 $(40,8 \%)$, ішемічно-гангренозною (ІГФ) - 45 (59,2\%). 3а глибиною ураження хворих із І ст. було 9 (12\%), II ст. - 16 (21\%), III ст. - 36 (47,3\%), IV ст. - 15 (19,7\%) (за МегітВагнером). Хворі з хронічною артеріальною недостатністю (XAH) IV ст., з 0 та V ступенями участь у дослідженні не брали. Контрольну групу склали 20 хворих, яких зіставили з досліджуваною групою, у яких вакуум-терапію не використовували (контрольна група). Хворим проводили загальне клініко-лабораторне та інструментальне обстеження, що включало: об'єктивне обстеження, збір скарг та анамнезу захворювання. Вивчали зміни мікрогемодинаміки нижніх кінцівок, проводили цитологічні, мікробіологічні та морфологічні дослідження. Отримані результати обробляли статистично відповідно до значень критерію Стьюдента, за допомогою комп'ютерних програм S-PLUS 2000, STATISTICA, Excell. Результати вважали достовірними при значеннях р<0,05. Вакуумтерапію використовували залежно від виду рани та виду хірургічної обробки. Терапевтичний вплив вакууму на ранові поверхні забезпечували за допомогою вакуумапарату АГАТ-ДНЕПР, з використанням від'ємного тиску в діапазоні 80-125 мм рт. ст. Для накладання вакуумних пов'язок використовували стандартні набори виробництва компанії V.A.C. GranuFoamDressing (USA). Кількісний та якісний склад мікрофрлори гострої рани визначали за допомогою бактеріологічного дослідженням ранового 
ексудату на день госпіталізації, 3; 6; 9 та 14 доби лікування.

РЕЗУЛЬТАТИ ДОСЛІДЖЕНЬ ТА ЇХ ОБГОВОРЕННЯ Хворим із гострими ранами проводили хірургічну обробку з подальшим застосуванням вакуумної терапії одразу після оперативного втручання (сила вакууму 50-80 мм рт. ст.) або на наступний день (сила вакууму - 100-120 мм рт. ст.). На момент госпіталізації з ранового вмісту виділено мікроорганізми, які віднесли до 5 родин, 6 родів та 32 видів, із загальною середньою колонізацією 7,41 lg КУО/г (табл. 1).

Стасрілококи склали найбільшу частку мікробних угруповань (45,8 \%) і були представлені 10 видами. Серед них домінуюче положення займали S. aureus $(53,22 \%)$, субдомінуюче - S. epidermidis $(21,25 \%)$ та S. intermedius $(14,13 \%)$, S. haemolyticus $(11,4 \%)$ із загальною щільністю $(8,46 \pm 0,82) \lg$ КУО/г. У загальній популяції стафрілококів понад 50 \% належать до коагулазопозитивних стасрілококів. Другу за значущістю групу мікроорганізмів у рановому вмісті склали мікрококи, серед яких домінуюче положення займали M. varians (35,72\%), M. luteus $(24,34$ $\%)$, M. Iylae (23,45 \%) та M. sedentarius (16,49 \%). Третю групу склали коринебактерії, які були представлені 7 видами. Серед них домінуюче положення займали C. ulcerans $(27,38 \%)$, C. xerosis $(20,41 \%)$, C. minutissimum $(19,43 \%)$. Аеробні спороутворювальні бацили були представлені 6 видами і склали близько 12,5 \% мікроорлори, яка виділялася з ранових дефектів у хворих, але за питомою вагою лише 2,97 \% усіх мікроорганізмів. Домінували В. cereus $(28,41 \%)$, та B. subtilis (22,16 \%), складаючи понад 50 \% загальної популяції бацил.

Стрептококи в рановому вмісті зустрічалися досить рідко (1,44 \%) і були представлені лише трьома видами 3 досить високою щільністю колонізації: Str. pyogenes (7,03 lg КУО/г), Str. mitis (6,75 lg КУО/г), Str. faecalis $(7,61$ lg КУО/г). Найбідніший видовий склад і найменша частота зустрічальності була притаманна ентеробактеріям $(1,01 \%)$ та псевдомонадам (0,66 \%). Серед цих мікроорганізмів були виділені Klebsiella oxytoca, Pseudomonas aeroginosa, та E. coli. У 68,4 \% хворих на основі характерної клінічної картини та мікроскопії нативного матеріалу з рани, забарвленого за Грамом, встановлено, що гнійно-запальний процес зумовлений анаеробною неклостридіальною фрлорою, для верифрікації якої необхідні спеціальні мікробіологічні дослідження. Частіше цей вид мікрофлори був у асоціаціях із грамнегативними та грампозитивними мікроорганізмами, переважно у хворих з НІФ СДС. Вивчення наявності мікробних асоціацій у гострих ранах показало, що у 55,8 \% пацієнтів спостерігалося поєднання 2-3 видів мікроорганізмів, у 34,8 \% 4-5, та у 9,4 \% була моноінфекція.

Найбільш часто мікробні асоціації були представлені стасрілококами з грамнегативними мікроорганізмами (62,1
\%), з грампозитивними мікроорганізмами (14,5 \%). Асоціації лише грампозитивних мікроорганізмів були у 17,6 \% пацієнтів, грамнегативних мікроорганізмів - у 5,8 \% випадків. У пацієнтів з абсцесами, фрлегмонами з ранових десектів частіше висівалася грампозитивна фрлора, а у хворих із гнійними ранами, при вологій гангрені - грамнегативна. В загальному переважала грамнегативна фрлора $(71,2 \%)$ над грампозитивною $(28,8 \%)$.

Загальні зміни щільності бактерійних угруповань у ранах під впливом вакуумної терапії наведено нижче. Аналіз результатів досліджень дозволив констатувати виражений позитивний вплив вакуум-терапії на кількісний склад мікрофрлори в ранах, який стосувався як грамнегативних, так і грампозитивних мікроорганізмів (табл. 2).

На 3-тю добу лікування спостерігалося зниження щільності мікроорганізмів, яке було більш виражене на тлі вакуумної терапії, однак це зниження не носило статистичної достовірності.

Лише кількість стасрілококів зменшилася на достовірному рівні $(p<0,05)$. 3 6-го дня вакуумної терапії відмічено статистично достовірне зниження всіх видів мікроорганізмів при використанні вакуумної терапії $(p<0,05)$. Piвень інфрікування ран знижувався менше критичних величин $\left(>10^{5}\right)$. У подальшому кількість мікроорганізмів продовжувала достовірно знижуватися. 3 9-го дня лікування у хворих цієї групи не висівалися стрептококи, а 3 14-го дня - ще мікрококи й аеробні бацили. Починаючи 3 6 доби, загальна щільність мікроорганізмів у групі хворих, які отримували вакуумну терапію, склала $(4,19 \pm 0,45) \mathrm{lg}$ КУО/г, що було достовірно нижче, ніж в контрольній гру$\Pi і-(5,88 \pm 0,66) \lg \mathrm{KУO} / г(p<0,05)$.

У контрольній групі пацієнтів достовірне зниження мікроорганізмів відмічено з 9-ї доби лікування, без зменшення видової кількості мікроорганізмів. Однак у 6 хворих основної групи і у 2 пацієнтів контрольної групи на 5-7 доби лікування було відмічено пролонгацію гнійно-запального процесу. Це було розцінено як реінфікування ран за рахунок внутрішньолікарняної інсрекції. Проведене мікробіологічне дослідження дозволило виділити у цих хворих Pseudomonas aeroginosa, Staphylococcus aureus, Klebsiella pneumonia, Proteus vulgaris, які були віднесені до внутрішньогоспітальної іноеекції. Найбільш значущими збудниками внутрішньолікарняної інфекції були Pseudomonas aeroginosa (76,2 \%), рідше зустрічався стафрілокок (51,8 \%). Пролонгація патологічного процесу потребувала повторних хірургічних обробок, що подовжило терміни лікування цих хворих.

Отже, мікробна спільнота гострих ранових дефектів у хворих із ССД представлена значною кількістю мікроорганізмів. Вакуумна терапія сприяє більш швидшій елімінації мікроорганізмів та збідненню її видового складу, що дозволяє швидше підготувати рану до пластичного закриття.

Таблиця 1. щільність бактерійних угруповань гострих ранових дефектів у хворих із синдромом стопи діабетика

\begin{tabular}{|l|c|}
\hline \multicolumn{1}{|c|}{ Угруповання мікроорганізмів } & Густота бактерій в гострій рані у хворих із ССД (Ig KУО/г) (n=76) \\
\hline Стасілококи & $8,46 \pm 0,82$ \\
\hline Стрептококи & $7,85 \pm 0,67$ \\
\hline Мікрококи & $7,24 \pm 0,84$ \\
\hline Коринебактерії & $7,58 \pm 0,87$ \\
\hline Ентеробактерії і псевдомонади & $7,14 \pm 0,74$ \\
\hline Аеробні бацили & $6,24 \pm 0,68$ \\
\hline Середні показники & $7,41 \pm 0,77$ \\
\hline
\end{tabular}


Таблиця 2. щільність бактерійних угруповань гострих ранових дефектів у хворих із синдромом стопи діабетика в процесі вакуумної терапії

\begin{tabular}{|c|c|c|c|c|c|}
\hline \multirow{2}{*}{ Угруповання мікроорганізмів } & \multicolumn{5}{|c|}{$\begin{array}{c}\text { Динаміка густоти бактерій в гострій рані у хворих із СДС на тлі вакуумної терапії (lg КУО/г) } \\
(\mathrm{n}=76)\end{array}$} \\
\hline & госпіталізація & 3-я доба & 6-та доба & 9-та доба & 14-та доба \\
\hline Стафрілококи & $8,46 \pm 0,62$ & $6,82 \pm 0,46^{*}$ & $4,82 \pm 0,35^{\star}$ & $3,47 \pm 0,27^{\star}$ & $2,16 \pm 0,48^{*}$ \\
\hline Стрептококи & $7,85 \pm 0,67$ & $6,19 \pm 0,63$ & $4,22 \pm 0,48^{*}$ & - & - \\
\hline Мікрококи & $7,24 \pm 0,84$ & $6,12 \pm 0,61$ & $3,84 \pm 0,54$ * & $2,15 \pm 0,08^{*}$ & - \\
\hline Коринебактерії & $7,58 \pm 0,87$ & $6,52 \pm 0,76$ & $4,75 \pm 0,47^{*}$ & $3,12 \pm 0,12^{*}$ & $1,42 \pm 0,04 *$ \\
\hline Ентеробактерії і псевдомонади & $7,14 \pm 0,74$ & $6,21 \pm 0,62$ & $4,23 \pm 0,62^{*}$ & $2,63 \pm 0,04 *$ & $1,28 \pm 0,05^{*}$ \\
\hline Аеробні бацили & $6,24 \pm 0,68$ & $5,12 \pm 0,45$ & $3,25 \pm 0,24 *$ & $1,67 \pm 0,06^{*}$ & - \\
\hline Середні показники & $7,41 \pm 0,77$ & $6,16 \pm 0,59$ & $4,18 \pm 0,45^{*}$ & $2,61 \pm 0,11^{*}$ & $1,62 \pm 0,19$ * \\
\hline \multicolumn{6}{|c|}{ Контрольна група (n=20) } \\
\hline Стафрілококи & $8,42 \pm 0,67$ & $7,64 \pm 0,82$ & $5,98 \pm 0,63^{*}$ & $5,12 \pm 0,43^{*}$ & $3,86 \pm 0,36^{*}$ \\
\hline Стрептококи & $7,81 \pm 0,82$ & $7,14 \pm 0,67$ & $6,37 \pm 0,62$ & $4,62 \pm 0,52^{*}$ & $3,57 \pm 0,41^{*}$ \\
\hline Мікрококи & $7,26 \pm 0,68$ & $6,54 \pm 0,58$ & $5,88 \pm 0,48$ & $3,89 \pm 0,28^{*}$ & $2,68 \pm 0,28^{*}$ \\
\hline Коринебактерії & $7,53 \pm 0,76$ & $6,21 \pm 0,52$ & $6,08 \pm 0,74$ & $4,28 \pm 0,34^{*}$ & $3,14 \pm 0,18^{*}$ \\
\hline Ентеробактерії і псевдомонади & $7,21 \pm 0,88$ & $6,12 \pm 0,68$ & $5,82 \pm 0,63$ & $4,23 \pm 0,41^{*}$ & $3,48 \pm 0,32^{*}$ \\
\hline Аеробні бацили & $6,28 \pm 0,52$ & $5,85 \pm 0,62$ & $5,14 \pm 0,83$ & $3,68 \pm 0,36^{*}$ & $2,45 \pm 0,18^{*}$ \\
\hline Середні показники & $7,41 \pm 0,72$ & $6,58 \pm 0,65$ & $5,87 \pm 0,61$ & $4,30 \pm 0,39 *$ & $3,20 \pm 0,29 *$ \\
\hline
\end{tabular}

Примітка. * p<0,05-0,01 порівняно з даними на момент госпіталізації.

Висновки 1. Мікробіологічне дослідження дало змогу встановити, що найбільшу частку мікробних угруповань склали стафрілококи, мікрококи, коринебактерії, аеробні спороутворювальні бацили, стрептококи, ентеробактерії, псевдомонади з загальною середньою колонізацією 7,41 lg КУО/г.

2. Використання вакуумної терапії до 6 доби дозволило знизити загальну щільність мікроорганізмів до
$(4,18 \pm 0,45) \lg$ КУО/г, що було достовірно нижче, ніж у контрольній групі - $(5,87 \pm 0,61) \lg$ КУО/г $(p<0,05)$. Відмічалося і значне зменшення видового розмаїття мікроорганізмів у рані.

3. Вакуумна терапія ран у хворих із ССД сприятливо впливає на перебіг ранового процесу і $€$ ефективним методом лікування, який дозволяє скоротити терміни стаціонарного лікування хворих на $(4,1 \pm 1,6)$ ліжко-дня.
СПИСОК ЛІТЕРАТУРИ

1. Абаев Ю. К. Раны и раневая инфекция : справочник хирурга / Ю. К. Абаев // Ростов-на-Дону : Феникс, 2006. - 427 с.

2. Вакуум-інстиляційна терапія у хворих синдромом діабетичної стопи / О. М. Бєсєдін, Ю. Ю. Малюк, Л. І. Карпенко [та ін.] // Клінічна хірургія. - 2014. - № 11 (3). - С. 8-10.

3. Синдром диабетической стопы в клинической практике / В. Н. Оболенский, Т. В. Семенова, П. Ш. Леваль, А. А. Плотников // Русский мед. журнал. - 2010. - № 2. - С. 45-58.

4. Удовиченко О. В. Диабетическая стопа / О. В. Удовиченко, Н. М. Грекова. - М. : Практическая медицина, 2010. - 272 с.

5. Храмилин В. Н. Современные аспекты местного лечения хронических ран нижних конечностей у больных сахарным ди- абетом / В. Н. Храмилин // Сахарный диабет. - 2005. - № 4. C. $1-8$.

6. Poly (ADP-ribose) polymerase is activated in subjects at risc of developing type 2 diabetes and is associated with impaired wascular reactivity / C. Szabo, A. Zanchi, K. Komjati [et al.] // Circulation. 2002. - Vol. 106. - P. 2680-2686.

7. Suzuki E. Prevalence and major risk factors of reduced flow volume in lower extremities with normal ankle-brechial index in Japanese patients with type 2 diabetes / E. Suzuki // Diabetes Care. - 2003. - P. 1443-1446.

8. The Foot in Diabetes, 3d. Ed. A. J .M. Boulton, H. Connor, 41. P. Cavanagh (eds). J. Wiley \& Sons. Inc. $-2000 .-364$ p.

Отримано 04.07.17

(CA. V. Pavlyshyn

I. Horbachevsky Ternopil State Medical University

CHANGES IN THE SPECIFIC STRUCTURE OF MICROFLORA AFTER THE VACUUM THERAPY OF ACUTE WOUND DEFECTS IN PATIENTS WITH DIABETIC FOOT SYNDROME

Summary. According to experts from the World Health Organization, the number of people with diabetes mellitus (DM) in the world currently exceeds 120 million and continues to grow exponentially. It is predicted that by 2030 there will be about 360 million patients on the planet.

The aim of the study - to learn the change in the quantitative and qualitative composition of the microflora in the application of vacuum therapy for acute wounds in patients with diabetic foot syndrome. 
Materials and Methods. On the basis of examination and treatment of 76 patients with diabetes mellitus, complications of diabetic foot syndrome have been studied the effect of vacuum therapy on the species composition of the microflora of acute wounds. Among the examined patients, there were were $49(64.5 \%)$ men, and 27 (35.5\%) women, aged from 48 to 72 . The average age of patients $-(64.7 \pm 4.5)$ years. The patients with diabetes mild degree were 12 , the average severity -47 , and the severe one -17 . All underwent general clinical and laboratory and instrumental examination: objective examination, collection of complaints and anamnesis of the disease, cytological, microbiological and morphological studies, therapeutic influence of the vacuum provided by vacuum - apparatus "AGAT-DNEPR", with negative pressure in the range of $80-125 \mathrm{~mm}$. $\mathrm{Hg}$. The quantitative and qualitative composition of the acute wound microflora was determined by bacteriological examination of the wound exudate on the day of admission, $3,6,9$ and 14 days of treatment.

Results and Discussion. The study of the presence of microbial associations in acute wounds showed that $55.8 \%$ of patients had a combination of 2-3 types of microorganisms, 34.8\% - 4-5, and $9.4 \%$ had monoinfection. Since 6 days, the total density of microorganisms in the group of patients receiving vacuum therapy was $(4.19 \pm 0.45) \mathrm{lg}$ CFU / $\mathrm{g}$, lower than in the control group (5.88 $\pm 0.66) \lg$ CFU $/ g(P<0.05)$. It has been proved that the use of vacuum for the treatment of acute wounds reduces the quantitative and specific composition of microorganisms in wound defects, which in turn reduces the hospitalization of patients on average (4.1 \pm 1.6) bed-days.

Key words: diabetes mellitus; diabetic foot syndrome; vacuum therapy.

()А. В. Павлишин

ГВУЗ “Тернопольский государственный медицинский университет имени И. Я. Горбачевского” ИЗМЕНЕНИЯ ВИДОВОГО СОСТАВА МИКРОФЛОРЫ ПОСЛЕ ИСПОЛЬЗОВАНИЯ ВАКУУМНОЙ ТЕРАПИИ ОСТРЫХ РАНЕВЫХ ДЕФЕКТОВ У БОЛЬНЫХ С СИНДРОМОМ СТОПЫ ДИАБЕТИКА

Резюме. Согласно данным экспертов Всемирной организации здравоохранения, количество больных сахарным диабетом (СД) в мире в настоящее время превышает 120 млн и продолжает расти в геометрической прогрессии. Прогнозируется, что к 2030 г. на планете будет около 360 млн больных.

Цель исследования - изучить изменение количественного и качественного состава микрофлоры при применении вакуумной терапии острых ран у больных с синдромом стопы диабетика.

Материалы и методы. На основе обследования и лечения 76 больных сахарным диабетом, осложненным синдромом стопы діабетика, изучено влияние применения вакуум-терапии на видовой состав микрофлоры острых ран. Среди обследованных

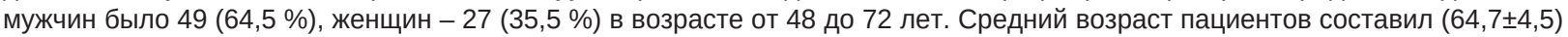
года. Больных СД легкой степени было 12 , средней тяжести - 47, тяжелой - 17 . Всем проводили общее клинико-лабораторное и инструментальное обследование: объективное обследование, сбор жалоб и анамнеза заболевания, цитологические, микробиологические и морорологические исследования, терапевтическое воздействие вакуума обеспечивали вакуум-аппаратом АГАТ-ДНЕПР с отрицательным давлением в диапазоне 80-125 мм рт. ст. Количественный и качественный состав микрофрлоры острой раны определяли с помощью бактериологического исследования раневого экссудата в день поступления, 3; 6; 9 и 14 сутки лечения.

Результаты исследований и их обсуждение. Изучение микробных ассоциаций в острых ранах показало, что у 55,8 \% пациентов наблюдалось сочетание 2-3 видов микроорганизмов, в 34,8 \% - 4-5, в 9,4 \% была моноинфекция. Начиная с 6 суток, общая плотность микроорганизмов в группе больных, получавших вакуумную терапию, составила $(4,19 \pm 0,45)$ lg КОЕ/г, что ниже, чем в контрольной группе - $(5,88 \pm 0,66) \lg \mathrm{KOE} / г(p<0,05)$. Доказано, что применение вакуума для лечения острых ран уменьшает количественный и видовой состав микроорганизмов в раневых дефектах, в свою очередь, позволяет сократить стационарное лечение больных в среднем на $(4,1 \pm 1,6)$ койко-дня.

Ключевые слова: сахарный диабет; синдром стопы диабетика; вакуумная терапия. 